\title{
Recommendations from a Portuguese Expert Group for Discontinuation of Tyrosine Kinase Inhibitors in Chronic Myeloid Leukemia Patients in Clinical Practice
}

\author{
Recomendações de um Grupo de Especialistas \\ Portugueses para Descontinuação de Inibidores \\ de Tirosina Cinase na Prática Clínica em Doentes \\ com Leucemia Mieloide Crónica
}

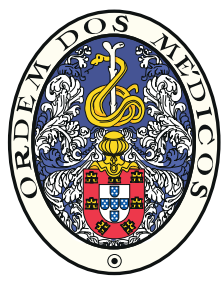

António ALMEIDA $\rrbracket^{1}$, Francesca PIERDOMENICO² ${ }^{2}$ Blanca Polo GUERRERO ${ }^{3}$, Filipa SARAIVA ${ }^{4}$, Ana MONTALVÃO $^{5}$, Jorge COUTINHO ${ }^{6}$, Mário MARIZ7 ${ }^{7}$ Teresa MELO ${ }^{8}$, Maria João SANTOS ${ }^{9}$, Alexandra PEREIRA $^{10}$, Nuno CERVEIRA $^{11}$ Acta Med Port 2019 Jul-Aug;32(7-8):550-557 • https://doi.org/10.20344/amp.11823

ABSTRACT

Until recently, the main goal of chronic myeloid leukemia therapy was disease control with the best overall survival, which required lifelong treatment. However, currently, the treatment-free remission concept is becoming an important goal in clinical practice, and several tyrosine kinase inhibitors discontinuation studies have shown that around $50 \%$ of patients with a durable deep molecular response beyond major molecular response successfully interrupt tyrosine kinase inhibitors for at least three years without loss of molecular response. However, and regardless of the existing evidence, the exact conditions for attempting treatment-free remission remain poorly defined. Different authors tried to guide the clinical decision regarding this topic but there are some points that differ, namely with respect to the recommended duration of tyrosine kinase inhibitors therapy and the appropriate molecular response prior to treatment-free remission. The goal of this article is to propose an algorithm to guide clinical practice in Portugal concerning chronic phase-chronic myeloid leukemia patients who wish to attempt treatment-free remission, since there are no national guidelines.

Keywords: Leukemia, Myelogenous, Chronic, BCR-ABL Positive; Portugal; Protein Kinase Inhibitors; Remission Induction

\section{RESUMO}

Até recentemente, o objectivo principal do tratamento da leucemia mielóide crónica era o controlo da doença com o maior tempo possível de sobrevivência, o que requeria tratamento durante toda a vida. No entanto, e actualmente, o conceito de remissão livre de tratamento está a tornar-se um objectivo importante na prática clínica, e vários estudos de descontinuação de inibidores de tirosina cinase mostraram que cerca de $50 \%$ dos doentes com uma resposta molecular profunda duradoura, para além da resposta molecular major, interrompem tratamento com inibidores de tirosina cinase com sucesso durante pelo menos três anos sem perda da resposta molecular. No entanto, e apesar da evidência existente, as condições concretas e exactas para tentar remissão livre de tratamento são ainda pouco conhecidas. Diferentes autores tentaram guiar a decisão clínica sobre este tópico mas alguns pontos permanecem não consensuais, nomeadamente no que respeita à duração recomendada de tratamento com inibidores de tirosina cinase e à resposta molecular apropriada antes de tentar remissão livre de tratamento. O objectivo desta publicação é propor um algoritmo que permita guiar a prática clínica em Portugal relativa a doentes com leucemia mielóide crónica ou em fase crónica que pretendam tentar remissão livre de tratamento, dada a ausência de recomendações nacionais.

Palavras-chave: Indução de Remissão; Inibidores de Proteínas Quinases; Leucemia Mielogénica Crónica BCR-ABL Positiva; Portugal

\section{INTRODUCTION}

Tyrosine kinase inhibitors (TKIs) changed the treatment and survival of patients with chronic myeloid leukemia $(\mathrm{CML})$ radically and are currently the cornerstone of $\mathrm{CML}$ treatment, improving outcomes and rendering CML a paradigm for molecular targeted therapy. Imatinib mesylate was the first adenosine triphosphate (ATP) competitive inhibitor of the fusion gene breakpoint cluster region-Abelson murine leukemia viral oncogene homolog 1 (BCR-ABL1) to receive approval for the treatment of patients with CML. ${ }^{1}$ Subsequently, other TKIs have been developed with a higher target specificity and potency. At present, five TKls are approved for the treatment of CML: imatinib (a first generation TKI), nilotinib, dasatinib, bosutinib (second generation TKIs), and ponatinib (a third generation TKI). ${ }^{2}$ The life

1. Department of Hematology. Hospital da Luz. Lisboa. Portugal.

2. Department of Hematology. Instituto Português de Oncologia. Lisboa. Portugal.

3. Department of Hematology. Hospital de Santa Maria. Centro Hospitalar Universitário Lisboa Norte. Lisboa. Portugal.

4. Department of Hematology. Hospital de Santo António dos Capuchos. Centro Hospitalar Lisboa Central. Lisboa. Portugal.

5. Department of Oncology. Hospital José Joaquim Fernandes. Unidade Local de Saúde do Baixo Alentejo. Beja. Portugal.

6. Department of Clinical Hematology. Centro Hospitalar e Universitário do Porto. Porto. Portugal.

7. Department of Onco-Hematology. Instituto Português de Oncologia. Porto. Portugal.

8. Department of Clinical Hematology. Centro Hospitalar de Vila Nova de Gaia/Espinho. Vila Nova de Gaia. Portugal.

9. Department of Clinical Hematology. Hospital Pedro Hispano. Unidade Local de Saúde de Matosinhos. Matosinhos. Portugal.

10. Department of Clinical Hematology. Centro Hospitalar e Universitário de Coimbra. Coimbra. Portugal.

11. Department of Genetics and Research Centre. Portuguese Oncology Institute. Porto. Portugal.

$\bowtie$ Autor correspondente: António M de Almeida. amalmeida@hospitaldaluz.pt

Recebido: 17 de janeiro de 2019 - Aceite: 12 de abril de 2019 | Copyright @ Ordem dos Médicos 2019 
expectancy of TKI-treated CML patients has been reported to be close to that of the general population. ${ }^{3}$

\section{Treatment free remission}

Until recently, the main goal of CML therapy was disease control with the best possible overall survival (OS) but with lifelong treatment. This was due to the fact that TKIs appear not to eradicate quiescent BCR-ABL $1^{+}$leukemia stem cells, regardless of the inhibition of $B C R-A B L 1$ activity. ${ }^{4}$ However, some patients achieve "molecularly undetectable disease for long periods of time", challenging physicians to attempt discontinuation of TKI therapy. ${ }^{5}$ Nevertheless, it should be highlighted that patients with a good response to TKIs and a controlled 'molecular disease' should not be exposed to unnecessary risks. ${ }^{6}$

Currently, the emergent treatment-free remission (TFR) concept is becoming an important goal in clinical practice. There are several reasons that render TFR an attractive strategy for patients and physicians such as: reducing treatment adverse events and avoiding long-term toxicities, improving patients' quality of life and alleviating the financial burden of TKI therapy, ${ }^{10}$ although the availability of generic imatinib has considerably reduced costs, and price is no longer an important issue for patients on imatinib. Since the pioneer STIM trial, ${ }^{11}$ such approach has been proposed in at least 29 discontinuation studies, involving around 2600 patients. ${ }^{12}$ TKI discontinuation studies have shown that about $50 \%$ of patients with durable deep molecular response (DMR) beyond major molecular response (MMR) successfully interrupt TKI for at least three years without loss of molecular response (MR). ${ }^{13,14}$

Another important issue is that if the patient has to resume TKI treatment, MMR is rapidly restored and no secondary resistances have been described. ${ }^{15}$ Of notice, after TKI discontinuation, $30 \%$ of patients present a reversible phenomenon called 'the TKI withdrawal syndrome' that includes pruritus and newly occurring or worsening musculoskeletal pain that tends to decrease over time. ${ }^{16}$ Musculoskeletal pain may require prescription of analgesics or non-steroidal anti-inflammatory drugs, and less frequently corticosteroids. The exact mechanism underlying this phenomenon is unknown and this syndrome disappears in patients who restart TKI therapy after a molecular relapse. Some authors argue that tapering TKI doses prior to discontinuation may attenuate such symptoms. , $16,17^{-17}$

One of the cornerstones of this strategy is molecular monitoring of the levels of BCR-ABL1 transcripts by realtime quantitative polymerase chain reaction (qRT-PCR). The International Scale (IS) standardized the quantification of BCR-ABL1 (BCR-ABL $1^{1 S}$ ), allowing for the comparison of results from different laboratories and harmonizing response definitions. ${ }^{18}$

Several clinical trials have shown that some Chronic Phase-CML (CP-CML) patients who achieved sustained DMR on TKI therapy can safely interrupt TKIs and attempt TFR. ${ }^{11,19-26}$ Most of these trials included patients treated with imatinib. ${ }^{11,19-23,26,27}$ Other studies involve patients treated with $2^{\text {nd }}$ generation TKIs nilotinib $6,22,24,26-30$ and dasatinib. $22.24-27,31$ Table 1 summarizes the results of different TFR trials.

There have been no reported progressions or deaths due to $C M L$ during the study periods of more than 2000 patients included in TFR trials. ${ }^{15}$ Only two events in this population have been reported, both occurring after restarting TKI and regaining MMR. In one patient enrolled in the ENETSfreedom trial, MMR loss was accompanied by the presence of a nilotinib-resistant F359V BCR-ABL1 mutation. ${ }^{29}$ However, it is known that some BCR-ABL1 mutations may persist at undetectable levels for many years, ${ }^{32}$ and it was not possible to determine if, in this patient, the mutation existed prior to TFR or emerged after nilotinib discontinuation. Also, in the A-STIM study, one patient who lost MMR after imatinib discontinuation experienced CML transformation into the lymphoid blast phase. ${ }^{20}$ No imatinib-resistant mutation was identified, but cytogenetic analyses revealed chromosomal anomalies in addition to the Philadelphia chromosome. Whether the BCR-ABL1+ lymphoid leukemic clone was selected during imatinib treatment, during the TFR phase, or after resuming imatinib therapy, remains unknown. Therefore, and although a formal causal link between TKI discontinuation and CML transformation into the lymphoid blast phase cannot be established, caution is needed in ongoing and future studies, since, albeit very rare, these are life-threatening events. ${ }^{15}$

Data from the TFR studies are enough to ensure safety for supervised attempts of TKI withdrawal. Nevertheless, and regardless of the existing evidence, the exact conditions for attempting TFR are still ill defined. Different authors tried to guide the clinical decision regarding this topic, including the most recent NCCN and ESMO Guidelines. ${ }^{13,33-36}$ However, there are some points that differ, namely with respect to the recommended duration of TKI therapy and the appropriate molecular response prior to TFR. ${ }^{13,34}$ Molecular milestones of the response to $\mathrm{TKI}$ treatment include early molecular response: $\mathrm{BCR}-\mathrm{ABL} 1^{\mathrm{Is}} \leq 10 \%$ at 3 months; MMR: $\mathrm{BCR}-$ $A B L 1^{1 s} \leq 0.1 \%$; DMR such as $M^{4}$ : BCR-ABL $1^{\text {Is }} \leq 0.01 \%$ and $\mathrm{MR}^{4.5}$ : BCR-ABL $1^{1 \mathrm{~s}} \leq 0.0032 \% .{ }^{18,37-39}$

The goal of this article is to propose an algorithm to guide clinical practice in Portugal concerning $\mathrm{CP}-\mathrm{CML}$ patients that wish to attempt TFR, since there are no national guidelines.

\section{Practical recommendations for TFR from an expert group}

Although there are some prognostic indicators of sustained TFR observed in clinical studies, most of them did not reach a significant prognostic value. Age and sex are undoubtedly not associated with sustained and successful TFR. The main factors associated with a sustained TFR are TKI treatment duration and depth of DMR. 1,11,13,25,27,29,40-42 These factors have been taken into consideration for the practical recommendations detailed below. 
Table 1 - Summary of ongoing TFR studies in patients with CP-CML

\begin{tabular}{|c|c|c|c|c|c|}
\hline Study & TKI treatment & $\begin{array}{l}\text { Elegibility for } \\
\text { attempting TFR }\end{array}$ & $\begin{array}{l}\text { Molecular Monitoring } \\
\text { during TFR }\end{array}$ & TFR & $\begin{array}{l}\text { Molecular } \\
\text { relapse - } \\
\text { trigger to } \\
\text { resume TKI }\end{array}$ \\
\hline $\begin{array}{l}\text { STIM }^{11} \\
(n=100)\end{array}$ & $\begin{array}{l}\text { Imatinib } 1^{\text {st }} \text { line or after } \\
\text { IFN- } \alpha\end{array}$ & $\begin{array}{l}\text { - At least } 3 \text { years of TKI } \\
\text { — MR4.5 with undetectable } \\
\text { BCR-ABL1 transcripts for } \\
\text { at least } 2 \text { years }\end{array}$ & $\begin{array}{l}\text { - Monthly for the } 1^{\text {st }} \text { year } \\
\text { - Every } 2 \text { months in year } 2 \\
\text { - Every } 3 \text { months thereafter }\end{array}$ & $\begin{array}{l}38 \% \\
\text { at } 24 \\
\text { months }\end{array}$ & $\begin{array}{l}\text { Loss of MMR } \\
\text { or increase in } \\
\text { BCR-ABL1 } \\
1 \text { log }\end{array}$ \\
\hline $\begin{array}{l}\text { TWISTER }^{19} \\
(\mathrm{n}=40)\end{array}$ & $\begin{array}{l}\text { Imatinib } 1^{\text {st }} \text { line or after } \\
\text { IFN- } \alpha\end{array}$ & $\begin{array}{l}\text { — At least } 3 \text { years of TKI } \\
\text { — MR4.5 with undetectable } \\
\text { BCR-ABL1 transcripts for } \\
\text { at least } 2 \text { years }\end{array}$ & $\begin{array}{l}\text { - Monthly for the } 1^{\text {st }} \text { year } \\
\text { - Every } 2 \text { months in year } 2 \\
\text { - Every } 3 \text { months thereafter }\end{array}$ & $\begin{array}{c}47 \% \\
\text { at } 24 \\
\text { months }\end{array}$ & $\begin{array}{l}\text { Loss of MMR } \\
\text { or confirmed } \\
\text { loss of MR4.5 }\end{array}$ \\
\hline $\begin{array}{l}\text { A-STIM }{ }^{20} \\
(n=80)\end{array}$ & $\begin{array}{l}\text { Imatinib } 1^{\text {st }} \text { line or after } \\
\text { IFN- } \alpha\end{array}$ & $\begin{array}{l}\text { — At least } 3 \text { years of TKI } \\
\text { — MR4.5 for at least } 2 \text { years }\end{array}$ & $\begin{array}{l}\text { - Monthly for the } 1^{\text {st }} \text { year } \\
\text { - Every } 2 \text { months in year } 2 \\
\text { - Every } 3 \text { months thereafter }\end{array}$ & $\begin{array}{l}64 \% \\
\text { At } 24 \\
\text { months }\end{array}$ & Loss of MMR \\
\hline $\begin{array}{l}\mathrm{KID}^{21} \\
(\mathrm{n}=90)\end{array}$ & $\begin{array}{l}\text { Imatinib } 1^{\text {st }} \text { line or after } \\
\text { IFN- } \alpha\end{array}$ & $\begin{array}{l}\text { - At least } 3 \text { years of TKI } \\
\text { — MR4.5 with undetectable } \\
\text { BCR-ABL } 1 \text { transcripts for } \\
\text { at least } 2 \text { years }\end{array}$ & $\begin{array}{l}\text { - Monthly for the first } 6 \text { months } \\
\text { - Every } 2 \text { months through } \\
\text { month } 12 \\
\text { - Every } 3 \text { months thereafter }\end{array}$ & $\begin{array}{l}59 \% \\
\text { at } 24 \\
\text { months }\end{array}$ & Loss of MMR \\
\hline $\begin{array}{l}\text { EURO-SKI }{ }^{26,27} \\
(n=750)\end{array}$ & $\begin{array}{l}\text { Imatinib } 1^{\text {st }} \text { line or } \\
\text { after IFN- } \alpha \text {, dasatinib } \\
\text { or nilotinib } 1^{\text {st }} \text { line } \\
\text { or subsequent line, } \\
\text { excluding patients with } \\
\text { resistance to any TKI }\end{array}$ & $\begin{array}{l}\text { - At least } 3 \text { years of TKI } \\
\text { - MR4 for at least } 1 \text { year }\end{array}$ & $\begin{array}{l}\text { - Every } 4 \text { to } 6 \text { weeks for the } \\
1^{\text {st }} \text { year } \\
\text { - Every } 3 \text { months in year } 2 \\
\text { and } 3\end{array}$ & $\begin{array}{c}50 \% \\
\text { at } 36 \\
\text { months }\end{array}$ & Loss of MMR \\
\hline $\begin{array}{l}\text { ISAV }^{23} \\
(n=112)\end{array}$ & $\begin{array}{l}\text { Imatinib } 1^{\text {st }} \text { line or after } \\
\text { IFN- } \alpha\end{array}$ & $\begin{array}{l}\text { - At least } 2 \text { years of TKI } \\
\text { - MR4 or MR4.5 with } \\
\text { undetectable BCR-ABL1 } \\
\text { transcripts for at least } \\
18 \text { months }\end{array}$ & $\begin{array}{l}\text { - Monthly for the first } 6 \text { months } \\
\text { — Every } 2 \text { months for } 36 \text { months }\end{array}$ & $\begin{array}{c}48 \% \\
\text { at } 36 \\
\text { months }\end{array}$ & Loss of MMR \\
\hline $\begin{array}{l}\mathrm{DADI}^{25} \\
(\mathrm{n}=88)\end{array}$ & $\begin{array}{l}\text { Dasatinib } 2^{\text {nd }} \text { or } \\
\text { subsequent line }\end{array}$ & $\begin{array}{l}\text { — At least } 1 \text { year dasatinib } \\
\text { — MR4 for at least } 1 \text { year }\end{array}$ & $\begin{array}{l}\text { - Monthly for the } 1^{\text {st }} \text { year } \\
\text { - Every } 3 \text { months in year } 2 \\
\text { - Every } 6 \text { months in year } 3\end{array}$ & $\begin{array}{l}48 \% \\
\text { at } 12 \\
\text { months }\end{array}$ & Loss of MR4 \\
\hline $\begin{array}{l}\text { DASFREE }^{53} \\
(n=84)\end{array}$ & $\begin{array}{l}\text { Dasatinib } 1^{\text {st }} \text { or } \\
\text { subsequent line }\end{array}$ & $\begin{array}{l}\text { — At least } 2 \text { years of TKI } \\
\text { — MR4.5 for at least } 1 \text { year } \\
\quad+3 \text { additional months of } \\
\text { MR4.5 confirmation }\end{array}$ & - Monthly for the $1^{\text {st }}$ year & $\begin{array}{l}63 \% \\
\text { at } 12 \\
\text { months }\end{array}$ & Loss of MMR \\
\hline $\begin{array}{l}\text { D-STOP } \\
(n=63)\end{array}$ & $\begin{array}{l}\text { Dasatinib } 1^{\text {st }} \text { or } \\
\text { subsequent line }\end{array}$ & $\begin{array}{l}\text { - At least } 2 \text { years of } \\
\text { dasatinib consolidation } \\
\text { — MR4 with undetectable } \\
\text { BCR-ABL1 transcripts for } \\
\text { at least } 2 \text { years }\end{array}$ & $\begin{array}{l}\text { - Monthly for the first } 6 \text { months } \\
\text { - Every } 2 \text { months through } \\
\text { month } 12 \\
\text { - Every } 3 \text { months thereafter }\end{array}$ & $\begin{array}{c}37 \% \\
\text { at } 12 \\
\text { months }\end{array}$ & $\begin{array}{l}\text { Confirmed } \\
\text { loss of MR4 }\end{array}$ \\
\hline $\begin{array}{l}\text { STOP 2G-TKI }{ }^{41} \\
(\mathrm{n}=60)\end{array}$ & $\begin{array}{l}\text { Dasatinib or nilotinib } \\
1^{\text {st }} \text { or subsequent line }\end{array}$ & $\begin{array}{l}\text { - At least } 3 \text { years } \\
\text { - MR } 4.5 \text { with undetectable } \\
\text { BCR-ABL } 1 \text { transcripts for } \\
\text { at least } 2 \text { years }\end{array}$ & $\begin{array}{l}\text { - Monthly for the } 1^{\text {st }} \text { year } \\
\text { - Every } 2-3 \text { months in year } 2 \\
\text { - Every } 3-6 \text { months thereafter }\end{array}$ & $\begin{array}{c}54 \% \\
\text { at } 48 \\
\text { months }\end{array}$ & Loss of MMR \\
\hline $\begin{array}{l}\text { STAT2 }{ }^{30} \\
(\mathrm{n}=96)\end{array}$ & Nilotinib $2^{\text {nd }}$ line & $\begin{array}{l}\text { - At least } 2 \text { years of nilotinib } \\
\text { consolidation } \\
\text { - MR4.5 for at least } 2 \text { years }\end{array}$ & $\begin{array}{l}\text { - Monthly for the } 1^{\text {st }} \text { year } \\
\text { - Every } 2 \text { months in year } 2 \\
\text { — Every } 3 \text { months thereafter }\end{array}$ & $\begin{array}{l}69 \% \\
\text { at } 12 \\
\text { months }\end{array}$ & $\begin{array}{l}\text { Confirmed } \\
\text { loss of MR4.5 }\end{array}$ \\
\hline $\begin{array}{l}\text { NILSt }{ }^{15} \\
(n=112)\end{array}$ & $\begin{array}{l}\text { Nilotinib } 1^{\text {st }} \text { or } \\
\text { subsequent line }\end{array}$ & $\begin{array}{l}\text { — At least } 2 \text { years of nilotinib } \\
\text { - MR4.5 for at least } 2 \text { years }\end{array}$ & $\begin{array}{l}\text { - Monthly for the first } 6 \text { months } \\
\text { - Every } 2 \text { months through } \\
\text { month } 12 \\
\text { - Every } 3 \text { months thereafter }\end{array}$ & $\begin{array}{c}59 \% \\
\text { at } 12 \\
\text { months }\end{array}$ & $\begin{array}{l}\text { Loss of } \\
\text { MR4.5 }\end{array}$ \\
\hline $\begin{array}{l}\text { ENESTop } \\
(n=163)\end{array}$ & Nilotinib $2^{\text {nd }}$ line & $\begin{array}{l}\text { - At least } 2 \text { years }+1 \\
\text { additional year of nilotinib } \\
\text { - MR4.5 for at least } 1 \text { years }\end{array}$ & $\begin{array}{l}\text { - Monthly for the first } 12 \text { months } \\
\text { - Every } 1.5 \text { months in year } 2 \\
\text { - Every } 3 \text { months thereafter }\end{array}$ & $\begin{array}{l}53.2 \% \\
\text { at } 22 \\
\text { months }\end{array}$ & $\begin{array}{l}\text { Loss of MMR } \\
\text { or confirmed } \\
\text { loss of MR4 }\end{array}$ \\
\hline $\begin{array}{l}\text { ENESTpath }{ }^{28} \\
(n=620)\end{array}$ & $\begin{array}{l}\text { Nilotinib } 2^{\text {nd }} \text { line in } \\
\text { the absence of MR4 } \\
\text { during imatinib therapy }\end{array}$ & $\begin{array}{l}\text { — Nilotinib for } 2 \text { or } 3 \text { years } \\
\text { — MR4 for at least } 1 \text { years }\end{array}$ & - & - & $\begin{array}{l}\text { Loss of MMR } \\
\text { or confirmed } \\
\text { loss of MR4 }\end{array}$ \\
\hline $\begin{array}{l}\text { ENESTfreedom }{ }^{29} \\
(n=215)\end{array}$ & Nilotinib $1^{\text {st }}$ line & $\begin{array}{l}\text { - At least } 2 \text { years }+1 \\
\text { additional year of nilotinib } \\
\text { — MR4.5 for at least } 1 \text { years }\end{array}$ & $\begin{array}{l}\text { - Monthly for the first } 12 \text { months } \\
\text { - Every } 1.5 \text { months in year } 2 \\
\text { - Every } 3 \text { months thereafter }\end{array}$ & $\begin{array}{l}48.9 \% \\
\text { at } 22 \\
\text { months }\end{array}$ & Loss of MMR \\
\hline
\end{tabular}




\section{Before attempting TFR}

1. Which are the patients in whom we can attempt TFR after $1^{\text {st }}$ line treatment?

The discontinuation of TKI treatment in CML should only be considered in individual patients with ensured access to certified molecular monitoring. ${ }^{13}$

The STIM study was pioneer in proposing the discontinuation of imatinib after at least three years of treatment in patients that had achieved at least an MR4.5 during two years. ${ }^{11}$ After the STIM study, several independent studies confirmed that TFR is feasible. The minimum duration of TKI therapy required for inclusion in TFR clinical trials has been as short as three years (Table 1). However, the median duration of previous TKI therapy was 5 to 8 years. ${ }^{33}$ In the large EURO-SKI trial, only $16 \%$ of patients had $<5$ years of prior TKI treatment. ${ }^{22}$

It has been reported that, in around $50 \%$ of cases, CML patients who achieve a sustained DMR for $1-2$ years can discontinue TKI therapy and maintain TFR without relapsing. Different studies have enrolled patients with either $\mathrm{MR}^{4}$ or MR4.5 (Table 1), however it is difficult to show a response gradient with a progressive increase in probability of TFR success. ${ }^{43}$ Patient inclusion criteria in the EURO-SKI trial were not so stringent: minimum duration of TKI therapy was three years and minimum duration of MR4 was one year. ${ }^{27,44}$

The STIM and TWISTER studies reported higher TFR rates in Sokal low-risk patients, although the difference was not statistically significant. ${ }^{11,19}$ In contrast, in the A-STIM study, no effect of the Sokal risk score was observed. ${ }^{20}$ The awaited results from other studies will help to clarify the role of the Sokal risk score in TFR success.

Achieving DMR is, therefore, a pre-requisite to select TFR candidates. ${ }^{33}$ Around $2 \%-3 \%$ of newly diagnosed cases of CML show atypical BCR-ABL1 transcripts and although these patients can be monitored and have their BCR-ABL1 levels quantified, the results cannot be expressed in the international scale. Therefore, with the exception of particular cases, these patients should not be eligible for TFR, since monitoring will not be as accurate and effective. ${ }^{33}$

\subsection{Time of treatment prior to TFR}

Recommendation: Patients should have at least five years of TKI treatment.

Comment: If $2^{\text {nd }}$ generation TKIs are used as $1^{\text {st }}$ line treatment, treatment duration can be shortened to a minimum of three years, since those TKIs induce faster and deeper responses. Patients who achieve an early molecular response at three months of treatment are in fact the best candidates for TFR.

\subsection{Minimum time of response and depth of response}

Recommendation: Patients should have a sustained $M^{4.5}$ for at least two years with at least three measurements during the year before attempting TFR.

\subsection{Type of BCR-ABL1 transcript}

Recommendation: To ensure accurate transcript quantification only patients harboring the typical BCR-ABL1 transcripts b2a2 (e13a2) and b3a2 (e14a2) should be candidates for TFR.

\subsection{Risk evaluation - The Sokal Risk Score}

Recommendation: Patients with low and intermediate Sokal risk score are the main candidates to attempt TFR.

\section{Which are the patients in whom we can attempt TFR after $2^{\text {nd }}$ line treatment?}

The experience with $2^{\text {nd }}$ generation TKIs as second line is more recent than that with first line imatinib. However, studies involving patients treated with dasatinib and nilotinib are of particular importance since these drugs are used not only to rescue patients facing imatinib failure (resistant patients) or intolerance (intolerant patients) but also to deepen molecular response (patients to deepen the response) achieved with imatinib.

Several trials have shown successful and safe discontinuation in patients who have achieved sustained DMR with second generation TKI. Intolerant patients have a higher likelihood of successful TFR than resistant patients. $6,25,29,31,41,45-47$

\subsection{Treatment interruption}

Recommendation: Only patients on second line TKI due to intolerance should be considered for treatment interruption.

\subsection{Duration of treatment prior to TFR}

Recommendation: Patients should be at least five years on TKI treatment. This period of time can include two TKIs if the first one used was withdrawn due to intolerance.

\subsection{Minimum time of response and which response}

Patients under $2^{\text {nd }}$ line TKIs should be divided in two groups:

a) Patients intolerant to $1^{\text {st }}$ line treatment under TKI treatment:

Recommendation: $1^{\text {st }}$ line criteria should be applied: MR4.5 for at least two years.

b) $2^{\text {nd }}$ line to deepen suboptimal molecular response: Recommendation: Patients should have an MR4.5 for at least 2 years after therapeutic switch. The Sokal risk score and type of transcripts criteria are the same as described for $1^{\text {st }}$ line treatment.

It should be clear that even after $2^{\text {nd }}$ line TKIs patients should have a deep response for at least two years provided the total duration of treatment is $\geq 5$ years.

\section{Monitoring during TFR attempt}

Highly sensitive and standardized molecular monitoring of BCR-ABL1 levels is key for ensuring the safety of patients attempting TFR, particularly during the first year, when the majority of molecular relapses occur, and more critically in 
the first six months after TKI cessation. ${ }^{11,19,25,40,41}$ Frequent molecular monitoring ensures that relapsing patients will be quickly identified, allowing prompt re-initiation of TKIs and re-achievement of molecular responses. ${ }^{48}$

\section{Molecular monitoring during TFR}

1.1 Time of laboratory result for molecular monitoring during TFR

Recommendation: Laboratories should issue qPCR results in a maximum time of one month. All tests should preferentially be performed in the same laboratory. Samples should be processed rapidly, within 24 to 36 hours, to minimize RNA degradation. This is especially important in centers that send their molecular samples to be tested at reference laboratories. In these cases, samples should be sent early during the week. The communication between laboratory-clinician-patient requires an efficient management system that must be ensured before attempting TFR.

\subsection{Laboratory results}

Recommendation: Results should have a sensitivity of at least MR4.5 and be standardized to BCR-ABL1's.

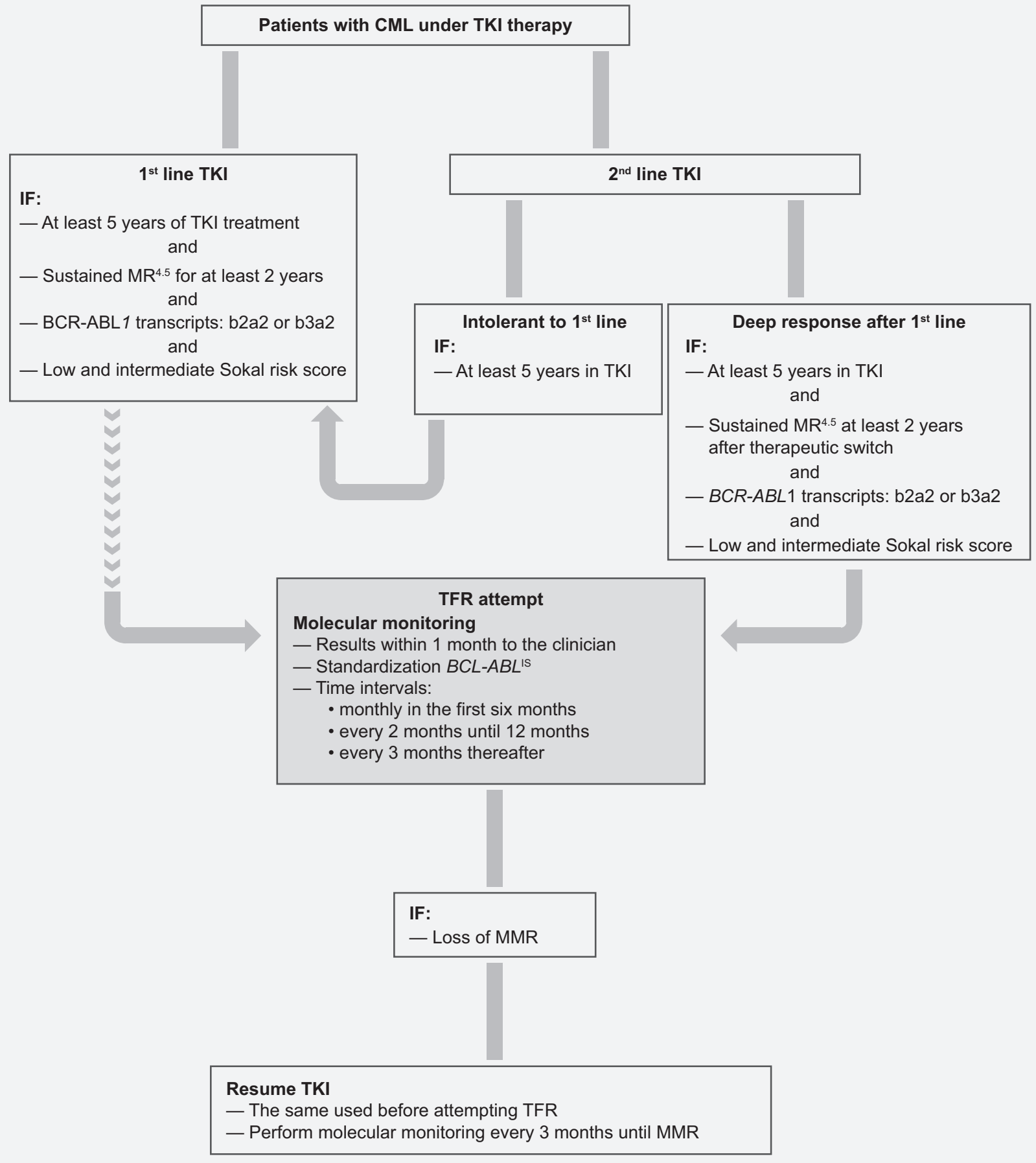

Figure 1 - Recommendations to guide the Portuguese medical community in attempting and managing TFR in patients with CP-CML 


\subsection{Intervals of molecular monitoring}

Recommendation: The molecular analysis should be performed monthly in the first six months, every two months until 12 months and every three months thereafter. This frequency must be accomplished and has to be guaranteed before attempting TFR.

\section{Trigger to resume TKIs}

A-STIM was the first study to demonstrate that the loss of MMR is a safe trigger to resume TKIs, a less stringent definition of molecular relapse than the one defined by the STIM or TWISTER protocols. ${ }^{20}$ Molecular relapse is not associated with disease progression ${ }^{5,20}$ and almost all patients regain DMR. ${ }^{11,19,49}$

Fluctuations in BCR-ABL1 levels, below the level of $0.1 \%$, can be observed in most patients that remain in TFR and are not necessarily associated with molecular relapse. The relapse is evaluated through the loss of MMR, that is a safe trigger for resuming treatment. ${ }^{15}$

Recommendation: TKI treatment should be resumed after loss of MMR. The presence of 'detectable disease' is not a trigger to resume TKI.

Comment: The same TKI used before TFR should be re-initiated after the loss of MMR. Molecular monitoring should be performed every three months until MMR.

Fig. 1 summarizes the recommendations of a Portuguese group of experts to guide the Portuguese medical community in attempting and managing TFR in patients with CP-CML.

\section{Second TFR attempt}

Data are required to support this strategy, such as the determination of biomarkers leading to relapse. Nevertheless, the possibility of a second attempt of TKI discontinuation after a first unsuccessful attempt exists. The RE-STIM study showed that a second TKI discontinuation attempt is safe and that a first failed attempt at discontinuing TKI does not preclude a second successful attempt, with patients regaining a deep molecular response. In this study, the probability to remain treatment-free in MMR after the second stop was $35 \%$ at 36 months. ${ }^{50}$ More studies are needed to confirm these results, and prospective trials addressing this issue are currently ongoing, such as the NILO postSTIM (NCT01774630) or the TRAD (NCT02268370). ${ }^{51}$

\section{Exceptional situations of necessary treatment stop}

These recommendations do not contemplate stopping TKI treatment for exceptional situations such as pregnancy or concomitant chemotherapy. Women with $\mathrm{CML}$ who wish to become pregnant are a specific population that needs TKI interruption since pregnancy whilst on TKls is not recommended due to the potential toxic effects for the embryo. ${ }^{10,52}$
These patients should be followed in a specialized center.

\section{Patient education}

Many patients may be reluctant to interrupt TKIs. To overcome this barrier, patients should be introduced to the concept of TFR early in their journey to help understand that TFR can be a therapeutic goal for some patients. It is important to inform the patients that TFR is a safe strategy that is unlikely to cause clinical relapse or disease progression. Moreover, patients should also be informed that molecular relapse may occur, particularly within the first 6 months of treatment discontinuation. In this reassuring communication strategy, it is also recommended mentioning the possibility of occurrence of withdrawal syndrome at an early stage of TFR, and that it is not a reason to resume TKIs, since symptomatic treatment can be used to manage it efficiently. Patients will also need education to adopt the mindset of being treatment-free and adjust to the more frequent molecular monitoring schedule. The importance of adherence to treatment should be emphasized since this is essential for TFR to be considered.

\section{CONCLUSION}

TFR is increasingly a treatment goal in CML. Herein, we aim to provide some guidance to Haematologists in Portugal regarding the attempt of TFR in patients with CP-CML.

It is important that patients provide their views regarding TFR, since psychological and emotional factors have to be considered as well. Patients should be selected for TFR on the basis of both their molecular criteria and their emotional resilience. At present, the duration of the treatment and the duration of DMR seem to be the only consistent predictors of success. Additional studies are warranted to identify novel biomarkers of value to accurately select candidate patients for TFR.

\section{FUNDING}

Funding for meetings and access to all necessary bibliography was provided by Novartis Portugal. Editorial assistance was provided by Irina Duarte, from X2-Science Solutions. This assistance was funded by Novartis Portugal. Novartis Portugal had no role in the writing of the manuscript or in the decision to submit the manuscript.

\section{CONFLICTS OF INTEREST}

António Almeida has received speaker fees from Celgene and Novartis.

Ana Montalvão has received speaker fees from Novartis.

Francesca Pierdomenico, Blanca Polo Guerrero, Filipa Saraiva, Jorge Coutinho, Mário Mariz, Teresa Melo, Maria João Santos, Alexandra Pereira and Nuno Cerveira have nothing to disclose. 


\section{REFERENCES}

1. Hochhaus A, Larson RA, Guilhot F, Radich JP, Branford S, Hughes TP, et al. Long-term outcomes of imatinib treatment for chronic myeloid leukemia. N Engl J Med. 2017;376:917-27.

2. Rosti G, Castagnetti F, Gugliotta G, Baccarani M. Tyrosine kinase inhibitors in chronic myeloid leukaemia: which, when, for whom? Nat Rev Clin Oncol. 2017;14:141-54.

3. Bower $H$, Bjorkholm M, Dickman PW, Hoglund $M$, Lambert PC, Andersson TM. Life expectancy of patients with chronic myeloid leukemia approaches the life expectancy of the general population. J Clin Oncol. 2016;34:2851-7.

4. Hamilton A, Helgason GV, Schemionek M, Zhang B, Myssina S Allan EK, et al. Chronic myeloid leukemia stem cells are not dependent on Bcr-Abl kinase activity for their survival. Blood. 2012;119:1501-10.

5. Rousselot P, Huguet F, Rea D, Legros L, Cayuela JM, Maarek O, et al Imatinib mesylate discontinuation in patients with chronic myelogenous leukemia in complete molecular remission for more than 2 years. Blood. 2007;109:58-60.

6. Hughes TP, Boquimpani C, Kim DW, Benyamini N, Clementino NC, Shuvaev V, et al. Treatment-free remission (TFR) in patients (pts) with chronic myeloid leukemia in chronic phase (CML-CP) treated with second-line nilotinib (NIL): first results from the ENESTop study. J Clin Oncol. 2016;34:7054

7. Boquimpani CM, Szczudlo T, Mendelson E, Benjamin K, Masszi T. Attitudes and perceptions of patients (pts) with chronic myeloid leukemia in chronic phase (CML-CP) toward treatment-free remission (TFR). Blood. 2014;124:4547.

8. Villemagne Sanchez LA, O'Callaghan C, Gough K, Hall K, Kashima Y Seymour JF, et al. Patient perceptions of treatment-free remission in chronic myeloid leukemia. Leuk Lymphoma. 2018;59:406-15.

9. Jiang Q, Liu Z-C, Zhang SX, Gale RP. Young age and high cost are associated with future preference for stopping tyrosine kinase inhibitor therapy in Chinese with chronic myeloid leukemia. J Cancer Res Clin Oncol. 2016;142:1539-47.

10. Berman E, Druker BJ, Burwick R. Chronic myelogenous leukemia: pregnancy in the era of stopping tyrosine kinase inhibitor therapy. J Clin Oncol. 2018;36:1250-6.

11. Mahon FX, Rea D, Guilhot J, Guilhot F, Huguet F, Nicolini F, et al Discontinuation of imatinib in patients with chronic myeloid leukaemia who have maintained complete molecular remission for at least 2 years: the prospective, multicentre Stop Imatinib (STIM) trial. Lancet Oncol. 2010;11:1029-35.

12. Goldberg SL, Savona M, Mauro MJ. Considerations for successfu treatment-free remission in chronic myeloid leukemia. Clin Lymphoma Myeloma Leuk. 2018;18:98-105.

13. Hochhaus A, Saussele S, Rosti G, Mahon FX, Janssen J, Hjorth-Hansen $\mathrm{H}$, et al. Chronic myeloid leukaemia: ESMO Clinical Practice Guidelines for diagnosis, treatment and follow-up. Ann Oncol. 2017;28:iv41-51.

14. Campiotti L, Suter MB, Guasti L, Piazza R, Gambacorti-Passerini C Grandi AM, et al. Imatinib discontinuation in chronic myeloid leukaemia patients with undetectable BCR-ABL transcript level: a systematic review and a meta-analysis. Eur J Cancer. 2017;77:48-56.

15. Rea D, Cayuela JM. Treatment-free remission in patients with chronic myeloid leukemia. Int J Hematol. 2018;108:355-64.

16. Richter J, Soderlund S, Lubking A, Dreimane A, Lotfi K, Markevarn B et al. Musculoskeletal pain in patients with chronic myeloid leukemia after discontinuation of imatinib: a tyrosine kinase inhibitor withdrawa syndrome? J Clin Oncol. 2014;32:2821-3.

17. Shah NP, Rousselot P, Schiffer C, Rea D, Cortes JE, Milone J, et al Dasatinib in imatinib-resistant or -intolerant chronic-phase, chronic myeloid leukemia patients: 7-year follow-up of study CA180-034. Am J Hematol. 2016:91:869-74.

18. Baccarani M, Deininger MW, Rosti G, Hochhaus A, Soverini S, Apperley JF, et al. European LeukemiaNet recommendations for the management of chronic myeloid leukemia: 2013. Blood. 2013;122:872-84.

19. Ross DM, Branford S, Seymour JF, Schwarer AP, Arthur C, Yeung DT, et al. Safety and efficacy of imatinib cessation for CML patients with stable undetectable minimal residual disease: results from the TWISTER study. Blood. 2013;122:515-22.

20. Rousselot $P$, Charbonnier A, Cony-Makhoul P, Agape P, Nicolini FE, Varet $\mathrm{B}$, et al. Loss of major molecular response as a trigger for restarting tyrosine kinase inhibitor therapy in patients with chronic-phase chronic myelogenous leukemia who have stopped imatinib after durable undetectable disease. J Clin Oncol. 2014;32:424-30.

21. Lee SE, Choi SY, Song HY, Kim SH, Choi MY, Park JS, et al
Imatinib withdrawal syndrome and longer duration of imatinib have a close association with a lower molecular relapse after treatment discontinuation: the KID study. Haematologica. 2016;101:717-23.

22. Mahon FX, Richter J, Guilhot J, Muller MC, Dietz C, Porkka K, et al Interim analysis of a pan European Stop Tyrosine Kinase Inhibitor trial in chronic myeloid leukemia : The EURO-SKI study. Blood. 2014;124:151.

23. Mori S, le Coutre P, Abruzzese E, Martino B, Pungolino E, Elena C, et al. Imatinib Suspension and Validation (ISAV) Study: results at 24 months. Blood. 2015;126:2775.

24. Rea D, Rousselot P, Guilhot F, Tulliez M, Nicolini FE, Guerci-Bresler A et al. Discontinuation of second generation (2G) tyrosine kinase inhibitors (TKI) in chronic phase (CP)-chronic myeloid leukemia $(\mathrm{CML})$ patients with stable undetectable <em>BCR-ABL</em> transcripts. Blood. 2012;120:916.

25. Imagawa J, Tanaka $\mathrm{H}$, Okada $\mathrm{M}$, Nakamae $\mathrm{H}$, Hino $\mathrm{M}$, Murai $\mathrm{K}$ et al. Discontinuation of dasatinib in patients with chronic myeloid leukaemia who have maintained deep molecular response for longer than 1 year (DADI trial): a multicentre phase 2 trial. Lancet Haematol. 2015;2:e528-35.

26. Saussele S, Richter J, Guilhot J, Hjorth-Hansen H, Almeida AMd, Janssen JJ, et al. "Duration of deep molecular response" has most impact on the success of cessation of tyrosine kinase inhibitor treatment in chronic myeloid leukemia - results from the EURO-SKI Trial. Blood. 2017; $130: 313$

27. Mahon FX, Richter J, Guilhot J, Hjorth-Hansen H, Almeida A, Janssen JJ et al. Cessation of tyrosine kinase inhibitors treatment in chronic myeloid leukemia patients with deep molecular response: results of the Euro-Ski Trial. Blood. 2016;128:787.

28. Rea D, Rosti G, Cross NCP, Hellman A, Niederwieser D, Pungolino E, et al. Enestpath: a phase III study to assess the effect of nilotinib treatment duration on treatment-free remission (TFR) in chronic phasechronic myeloid leukemia (CP-CML) patients (pts) previously treated with imatinib: interim analysis from the first year of linduction phase. Blood. 2015;126:4040.

29. Hochhaus A, Masszi T, Giles FJ, Radich JP, Ross DM, Gomez Casares MT, et al. Treatment-free remission following frontline nilotinib in patients with chronic myeloid leukemia in chronic phase: results from the ENESTfreedom study. Leukemia. 2017;31:1525-31.

30. Takahashi N, Nishiwaki K, Nakaseko C, Aotsuka N, Sano K, Ohwada C et al. Treatment-free remission after two-year consolidation therapy with nilotinib in patients with chronic myeloid leukemia: STAT2 trial in Japan. Haematologica. 2018;103:1835-42.

31. Kumagai T, Nakaseko C, Nishiwaki K, Yoshida C, Ohashi K, Takezako N, et al. Dasatinib cessation after deep molecular response exceeding 2 years and natural killer cell transition during dasatinib consolidation. Cancer Sci. 2018:109:182-92.

32. Parker WT, Yeoman AL, Jamison BA, Yeung DT, Scott HS, Hughes TP et al. BCR-ABL1 kinase domain mutations may persist at very low levels for many years and lead to subsequent TKI resistance. $\mathrm{Br} \mathrm{J}$ Cancer. 2013;109:1593-8.

33. Hughes TP, Ross DM. Moving treatment-free remission into mainstream clinical practice in CML. Blood. 2016;128:17-23.

34. National Comprehensive Cancer Network. NCCN Guidelines Version 4.2018 Chronic Myeloid Leukemia. [accessed 2019 Apr 04]. Available from: https://www.nccn.org/professionals/physician_gls/. 2018.

35. Mahon FX. Treatment-free remission in CML: who, how, and why? Hematology Am Soc Hematol Educ Program. 2017;2017:102-9.

36. Jabbour E, Kantarjian H. Chronic myeloid leukemia: 2018 update on diagnosis, therapy and monitoring. Am J Hematol. 2018;93:442-59.

37. Cross NC, White HE, Muller MC, Saglio G, Hochhaus A. Standardized definitions of molecular response in chronic myeloid leukemia. Leukemia. 2012;26:2172-5.

38. Cross NC, White HE, Colomer D, Ehrencrona H, Foroni L, Gottardi E, et al. Laboratory recommendations for scoring deep molecular responses following treatment for chronic myeloid leukemia. Leukemia. 2015;29:999-1003

39. Mahon FX, Etienne G. Deep molecular response in chronic myeloid leukemia: the new goal of therapy? Clin Cancer Res. 2014:20:310-22.

40. Etienne G, Guilhot J, Rea D, Rigal-Huguet F, Nicolini F, Charbonnier A et al. Long-term follow-up of the French Stop Imatinib (STIM1) Study in patients with chronic myeloid leukemia. J Clin Oncol. 2017;35:298-305.

41. Rea D, Nicolini FE, Tulliez M, Guilhot F, Guilhot J, Guerci-Bresler A, et al. Discontinuation of dasatinib or nilotinib in chronic myeloid leukemia: interim analysis of the STOP 2G-TKI study. Blood. 2017;129:846-54. 
42. Hochhaus A, Mahon FX, le Coutre P, Petrov L, Janssen J, Cross NC et al. Nilotinib first-line therapy in patients with Philadelphia chromosomenegative/BCR-ABL-positive chronic myeloid leukemia in chronic phase: ENEST1st sub-analysis. J Cancer Res Clin Oncol. 2017;143:1225-33.

43. Hughes TP. Treatment free remission for chronic myeloid leukemia in 2017. Clin Lymphoma Myeloma Leuk. 2017;17:S102-4.

44. Saussele S, Richter J, Guilhot J, Gruber FX, Hjorth-Hansen H, Almeida A, et al. Discontinuation of tyrosine kinase inhibitor therapy in chronic myeloid leukaemia (EURO-SKI): a prespecified interim analysis of a prospective, multicentre, non-randomised, trial. Lancet Oncol. 2018;19:747-57.

45. Okada M, Imagawa J, Tanaka H, Nakamae H, Hino M, Murai K, et al. Final 3-year results of the dasatinib discontinuation trial in patients with chronic myeloid leukemia who received dasatinib as a second-line treatment. Clin Lymphoma Myeloma Leuk. 2018;18:353-60.

46. Tiribelli M, Bonifacio M, Binotto $G$, lurlo A, Cibien F, Maino $E$, et al. Excellent outcomes of 2G-TKI therapy after imatinib failure in chronic phase CML patients. Oncotarget. 2018;9:14219-27.

47. Hughes A, Yong AS. Immune effector recovery in chronic myeloid leukemia and treatment-free remission. Front Immunol. 2017;8:469.
48. Dulucq S, Mahon FX. Deep molecular responses for treatmentfree remission in chronic myeloid leukemia. Cancer Medicine. 2016;5:2398-411.

49. Rea D, Guilhot J, Guilhot F, Huguet F, Nicolini FE, Legros L, et al. Long term follow-up after imatinib cessation for patients in deep molecular response: the update results of The STIM1 Study. Blood. 2013;122:255.

50. Legros L, Nicolini FE, Etienne G, Rousselot P, Rea D, Giraudier S, et al. Second tyrosine kinase inhibitor discontinuation attempt in patients with chronic myeloid leukemia. Cancer. 2017;123:4403-10.

51. Rea D, Mahon FX. How I manage relapse of chronic myeloid leukaemia after stopping tyrosine kinase inhibitor therapy. $\mathrm{Br} \mathrm{J}$ Haematol. 2018;180:24-32.

52. Palani R, Milojkovic D, Apperley JF. Managing pregnancy in chronic myeloid leukaemia. Ann Hematol. 2015;94:S167-76.

53. Shah NP, Garcì-Gutiérrez V, Jiménez-Velasco A, Larson S, Saussele S, Rea D, et al. Updated 18-month results from Dasfree: a study evaluating dasatinib discontinuation in patients (Pts) with chronic myeloid leukemia in chronic phase (CML-CP) and deep molecular response (DMR) Blood. 2018;132:Abstract 4253. 